\title{
Hydatid Cyst Presenting with Mass That Localized in the Cruris Region
}

Kruris Bölgesine Lokalize Kitle İle Prezente Olan Kist Hidatik

\author{
Fatih Bağcıer ${ }^{1}$ Osman Onaç², Meltem Alkan Melikoğlu
}

${ }^{1}$ Atatürk Üniversitesi Tıp Fakültesi Hastanesi, Fiziksel Tıp ve Rehabilitasyon Anabilim Dalı, Erzurum, Türkiye

${ }^{2}$ Metin Sabancı Baltalimanı Eğitim ve Araştırma Hastanesi, Ortopedi ve Travmatoloji Anabilim Dalı, İstanbul, Türkiye

To the Editor:

A 40-year-old male was referred to our hospital with a slowly growing mass that localized in his right cruris under the knee. He had moderate pain without any daily distraction. His history was not relevant with trauma or septic disease. He did not have pain localized in the abdomen and chest. A physical examination revealed a $5 \times 4 \mathrm{~cm}$ fixed, firm, and tender mass in the anteromedial and middle parts of the right cruris. There was no ecchymosis, erythema, increased warmth, or lymphadenopathy. Laboratory tests were normal and showed a total leukocyte count of $4000 / \mathrm{mm}^{3}$, erythrocyte sedimentation rate of $25 \mathrm{~mm} / \mathrm{h}$, and C-reactive protein level of $1.2 \mathrm{mg} / \mathrm{dl}$. An ultrasound examination was first performed, and it showed multiple cystic lesions in the muscle localized in the gastrocnemius. Magnetic resonance imaging (MRI) was performed for further imaging. MRI showed an oval cystic mass of approximately $50 \times 30 \mathrm{~mm}$ in the gastrocnemius muscle, containing round daughter cysts (Figure 1). The cysts seen hypointense in T1 A-weighted images and hyperintense in T2 A-weighted images. Because the magnetic resonance images were suggestive of a hydatid cyst, further laboratory and imaging studies were employed to support the diagnosis and detect other sites of possible involvement. There was no other involvement of the hydatid cyst. There was a positive response to the indirect hemagglutination test for hydatid disease. The mass was operated. Albendazole therapy, 200 mg twice daily, was given for six weeks after the operation. Clinical, radiological, and serological tests showed no recurrence after the therapy.

Hydatic disease is a zoonotic infection caused by Echinococcus granulosus. E. granulosus frequently causes pulmonary and liver infection. Soft tissue hydatid disease is
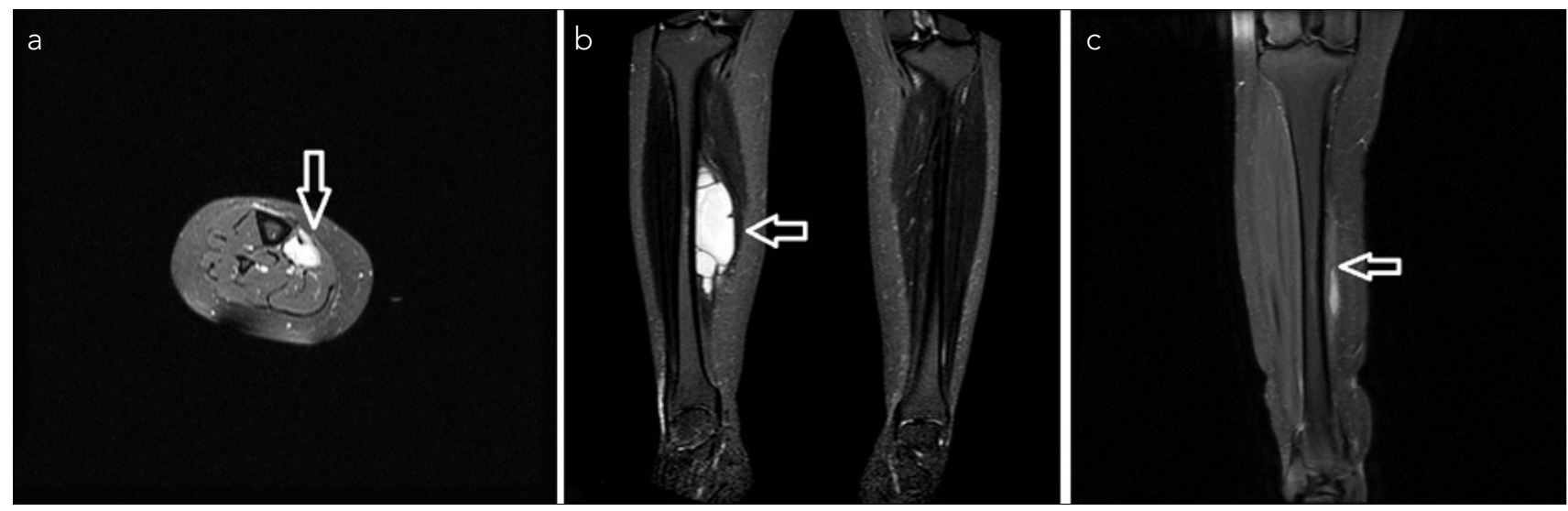

Figure 1. a-c. a. Axial fat-suppressed T2-weighted image, b. Coronal fat-suppressed T2-weighted image oval cystic mass of approximately $50 \times 30 \mathrm{~mm}$ in the gastrocnemius muscle, containing round daughter cysts, c. Coronal fat-suppresed T2-weighted image

Address for Correspondence / Yazışma Adresi: Dr. Fatih Bağcıer E.mail: bagcier_42@hotmail.com DOI: 10.5152/tpd.2016.4388

CCopyright 2016 Turkish Society for Parasitology - Available online at www.tparazitolderg.org

OTelif hakkı 2016 Türkiye Parazitoloji Derneği - Makale metnine www.tparazitolderg.org web sayfasından ulaşılabilir. 
unusual even in endemic areas, and skeletal muscle involvement is extremely rare, with a reported prevalence of $0.5-4.7 \%$ (1). Although there are many reports on intramuscular hydatid cysts, there are only a few in children (2). The diagnosis of musculoskeletal hydatid cysts is clinically and radiologically difficult. It resembles a soft tissue tumor. Ultrasonography, computed tomography, and MRI have a valuable role in the radiological diagnosis and follow-up of hydatid disease (3). A double-layered wall, daughter cysts, and the water lily sign are specific findings (4). We do not recommend routine biopsy. Surgery is most effective for treating hydatid cysts. Surgical resection and medical therapy are the preferred treatments for isolated echinococcosis. Hydatid cysts should be kept in mind when observing the soft tissue mass of the extremities in patients from areas endemic to $E$. granulosus.

Ethics Committee Approval: Ethics committee approval was received.

Informed Consent: The informed consent was received.

Peer-review: Externally peer-reviewed.

Author contributions: Consept - F.B.; Design - O.O.; Supervision - F.B.; Funding - F.B.; Materials - F.B.; Data Collection and/or Processing - M.A.M.; Analysis and/or Interpretation - M.A.M.; Literature Review - M.A.M.; Writer - M.A.M.; Critical Review M.A.M.
Conflict of Interest: Fatih Bağcıer. Financial Disclosure: None.

Etik Komite Onayı: Etik komite onayı alındı.

Hasta Onamı: Hasta onamı alınmıştır.

Hakem Değerlendirmesi: Dış Bağımsız.

Yazar Katkıları: Fikir - F.B.; Tasarım - O.O.; Denetleme - F.B.; Kaynaklar - F.B.; Malzemeler - F.B.; Veri Toplanması ve/veya İşlemesi - M.A.M.; Analiz ve/veya Yorum - M.A.M.; Literatür Taraması - M.A.M.; Yazıyı Yazan - M.A.M.; Eleştirel Inceleme M.A.M.

Çıkar Çatışması: Fatih Bağcıer.

Finansal Destek: Yok.

\section{REFERENCES}

1. Dahniya M.H., Hanna R.M., Ashebu S., Muhtaseb S.A., el-Beltagi A., Badr S., et al. The imaging appearances of hydatid disease at some unusual sites. Br J Radiol 2001; 74: 283-9. [CrossRef]

2. Dudkiewicz I., Salai M., Apter S. Hydatid cyst presenting as a soft-tissue thigh mass in a child. Arch Orthop Trauma Surg 1999; 119: 474-5. [CrossRef]

3. Guthrie J.A., Lawton J.O., Chalmers A.G. Case report: The MR appearances of primary intramuscular hydatid disease. Clin Radiol 1996; 51: 377-9. [CrossRef]

4. Garcia-Diez A.I., Ros Mendoza L.H., Villacampa V.M., Cozar M., Fuertes M.I. MR1 evaluation of soft tissue hydatid disease. Eur Radiol 2000; 462-6. [CrossRef] 